\title{
Delineation of Soil Fertility and Correlation Study of Different Nutrients in Soils of Chunar, Mirzapur, India
}

\author{
Puja Singh*, Surendra Singh and Ashish Rai
}

Department of Soil Science and Agricultural Chemistry, Institute of Agricultural Sciences, Banaras Hindu University, Varanasi-221005, Uttar Pradesh, India

*Corresponding author

\section{A B S T R A C T}

Keywords

Indo-Gangetic plain, Correlation analysis,

Exchangeable cations, Soil fertility

Article Info

Accepted:

04 October 2019

Available Online:

10 November 2019
Soil fertility is function of nutrient availability in the soil. Continuous cropping in the same piece of land results to nutrient exhaustion. In recent past, rapid decline of soil fertility in Indo-Gangetic plain drawing attention of researchers. To know fertility and nutrients availability in alluvial soil of Mirzapur this experiment was conducted and correlation between different nutrients were traced. Altogether 45 surface soil samples were collected and analyzed for different soil parameters. Results obtained showed that organic carbon was medium to high, nitrogen was extremely low, phosphorus and potassium were high, exchangeable cations ( $\mathrm{Ca}$ and $\mathrm{Mg}$ ) were adequate and sulphur was medium. On correlation analysis it was found that $\mathrm{pH}$ and $\mathrm{EC}$ were significantly and negatively correlated to each other. Significant positive correlation existed between EC and phosphorus, $\mathrm{EC}$ and potassium, $\mathrm{OC}$ and $\mathrm{Fe}$, phosphorus and $\mathrm{Fe}$, potassium and $\mathrm{Fe}, \mathrm{Ca}$ and $\mathrm{Mg}, \mathrm{Ca}$ and $\mathrm{Cu}$ and between $\mathrm{Fe}$ and $\mathrm{Cu}$ while $\mathrm{Cu}$ and $\mathrm{Zn}$ showed significant negative correlation.

\section{Introduction}

Fertility of soil is the capacity of soil to supply nutrients in adequate amount which itself is function of nutrient reserve in the soil. The optimum plant growth and yield depends not only on the nutrient reserve in the soil but also on their availability at a particular time which in turn is controlled by physical and chemical properties of the soil. Thus we need to maintain this nutrient reserve to get sustainable yield year after year. But it has been noticed in Indo-Gangetic plain that because of continuous rice-wheat cultivation (over 10.5 million ha), fertility of soil is deteriorating day by day, raising a serious problem to the sustainability of Indian agriculture as this part is a major agriculture 
belt of the India. Intensive farming, imbalanced fertilizer dose and faulty agriculture practices during Green Revolution period resulted to soil degradation, depletion of soil organic carbon (SOC), and environment problem as well (Ladha et al., 2003; Timsina and Connor, 2001). Imbalanced fertilizers application is a serious threat to sustainability. At the same time to increase productivity from the limited arable land we are in need of external supplement of plant nutrients. But excessive use of fertilizer is always hazardous to the soil and environment as well.

Soil test-based fertilizer recommendation is an effective management tool for increasing productivity of agricultural soils while maintaining sustainability (Srinivasarao et al., 2010; Sahrawat et al., 2010). As soil testing provide information regarding nutrient availability in soils which forms the basis for the fertilizer recommendations for maximizing crop yields (Doneriya et al., 2013). There are several factors hindering adoption of soil testing based fertilizer recommendation in India such as fragmented land, prevalence of small size holding, lack of infrastructural facilities etc (Sen et al., 2006). In addition to these constraints, monoculture and intensive farming practices are resulting to mining of the nutrients and decrease in soil fertility. Thus replenishment of these removed nutrients become essential for maintaining soil fertility and productivity (Kumar et al., 2013). Though, decomposition of crop residue results to partial replenishment of the nutrient but in order to meet actual nutrient demand of crops supplying of nutrients by means of nutrients become essential. Nowadays, widespread deficiency of macro, secondary and micronutrients are emerging in arable land (Singh et al., 2015; Rai and Singh, 2018a; Rai and Singh, 2018b; Krishan et al., 2018) in soils of eastern UP. These deficiencies are so severe and resulting in the emergence of visual symptoms on crops; thus, significant response has been reported on applying fertilizers to crops. Among all the agricultural inputs, it is the fertilizers that alone contribute to $50 \%$ of yield enhancement (Stewart et al., 2005). To get benefit of fertilizers application, they should be applied at the right time, right place and right quantity. Sometime conversion of the natural ecosystem into agricultural land under intensive cultivation severely deplete SOC, thus judicious management of soil under competing and diverse land use is the key to increase soil organic matter (Kumar et al., 2013). Soil testing is determining factor in decision making by farmers regarding type and quantity of fertilizers as per crop and soil requirement. This help in avoiding overfertilization which might results to nutrient leaching, water pollution and irreversible harm to aquatic life. Keeping this view in mind an attempt was made to analyze soil in Chunar block of Mirzapur district. The objective of the study was to prepare a comprehensive database about the nutrient status of the soils of Chunar block of Mirzapur and to know about deficient nutrient so that decline in fertility can be arrested. Chunar block belongs to the great Gangetic plains (Singh and Gangwar, 1971). Soil of Chunar is transported basaltic type of alluvium and can be considered as zonal lithomorphic variety. Alluvial deposits are of two types: new alluvium (lowland fresh deposits known as Khadar) and the old alluvium (highland deposits liable to denudation it is bangar). Soil of this region is loose, sandy but alkaline in $\mathrm{pH}$ und vulnerable to various erosional forces. It always remains in pedologically young condition by repeated input of silt.

\section{Materials and Methods}

Altogether 45 surface soil samples $(0-15 \mathrm{~cm})$ were collected from Gangpur village of Chunar block in Mirzapur. For collection of soil samples, the field was divided into the 
homogenous unit and one composite sample was collected from each sub-unit. Sampling spots were identified by moving in a zig-zag manner. After collection of soil samples, processing was done in soil processing laboratory of the Department of Soil Science and Agricultural Chemistry, IAS, BHU, Varanasi.

Soil $\mathrm{pH}$ was determined by combined electrode method (Chopra and Kanwar, 1982); electrical conductivity by conductivity meter (Sparks, 1996); Organic carbon by wet digestion method (Walkley and Black, 1934); available $\mathrm{N}$ by alkaline permanganate method (Subbiah and Asija, 1956); available P by Olsen's method (Olsen, 1954); K by ammonium acetate method (Hanway and Heidel, 1952). Available $S$ was determined using $0.15 \% \mathrm{CaCl}_{2}$ (Chesnin and Yien, 1950); cationic micronutrients ( $\mathrm{Fe}, \mathrm{Mn}, \mathrm{Cu}, \mathrm{Zn}$ ) were determined through AAS (Atomic absorption spectrophotometer) using 0.5 M DTPA as an extractant (Lindsay and Norway, 1978); while available B by hot water method (Berger and Troug, 1939). Data obtained was analyzed statistically and correlation coefficient was found between relevant physicochemical properties and soil available nutrients. Data obtained were analyzed statistically and correlation was fetched between relevant physicochemical properties and soil available nutrients.

\section{Results and Discussion}

A descriptive statistics and status of nutrients are summarized in tables $1-5$ and figure 1, respectively. Mean value of the $\mathrm{pH}$ obtained was 8.63 while that of EC was 0.19 , range of organic carbon found between 3.10-8.81 g per $\mathrm{kg}$ of soil with mean of 5.95. Available nitrogen was extremely low with mean value $159.60 \mathrm{~kg} / \mathrm{ha}$, the highest value of available nitrogen was $225.79 \mathrm{~kg} / \mathrm{ha}$. Available phosphorus varied between $7.36-61.43 \mathrm{~kg} / \mathrm{ha}$ with mean of 26.81, in case of potassium obtained mean value was $253.45 \mathrm{~kg} / \mathrm{ha}$ with wide variation in range (100.80-728.00). Results in case of $\mathrm{N}$ and $\mathrm{P}$ were in agreement with result of Ghosh (2017). All the cationic nutrients including exchangeable and micronutrient were adequate. Medium organic carbon content of this region might be due to addition of organic material by the farmers.

As per report of Tiwari et al., (2003) in Vindhyan soil, low-laying areas are having higher $\mathrm{C} / \mathrm{N}$ ratio than that of upland due to presence of sandstone, limestone and shale in low lying area. All the soil samples from both the villages were rated to be low in $\mathrm{N}$ instead of being rich in organic matter. There might be several reasons of poor $\mathrm{N}$, such as inadequate addition of nitrogenous fertilizers or excessive loss of $\mathrm{N}$ from rhizosphere through leaching or denitrification of nitrate form. Volatization of ammonical form may also be the reason preventing buildup of nitrogen in soil of this region. Hence low level of nitrogen is a matter of great concern to attain sustainable and intensive agriculture system as reported by Yadav et al., (2001).

Available phosphorus ranged between 7.36 to $61.43 \mathrm{~kg} \mathrm{ha}^{-1}$ with the mean value of $26.84 \mathrm{~kg}$ $\mathrm{ha}^{-1}$. In case of phosphorus result obtained was in agreement what reported by Singh et al., (2017). Earlier, these regions were reported to be low in phosphorus by Yadav et al., (2001) but gradual increase in soil $\mathrm{P}$ suggest higher rate of phosphorus application in crops by farmers of this region. Available potash ranged from 100.80 to $728 \mathrm{~kg} \mathrm{ha}^{-1}$ with mean of $253.45 \mathrm{~kg} \mathrm{ha}^{-1}$. High $\mathrm{K}$ in soil is because of dominance of Illitic clay mineral in IndoGangetic Plains (Dhaliwal and Gupta, 2006). Illitic clay minerals are weathered form of muscovite and mica clays. Edges of the illitic clay are frayed and wedged open, exposing the interior potassium located deeper within the clay layers. Exchangeable $\mathrm{Ca}$ and $\mathrm{Mg}$ were 
found to be sufficient level in the alluvial soil. $0.15 \% \mathrm{CaCl}_{2}$ extractable available sulphur ranged between $3.73-36.95 \mathrm{mg} \mathrm{kg}^{-1}$ with the mean value of $15.84 \mathrm{mg} \mathrm{kg}^{-1}$. The result was similar to mean reported by Singh et al., (2015). Majority of soil samples had sufficient level of available $S$ in both the villages. High level of available $S$ in these soils may be probably due to high content of Organic carbon.

On correlation study it is found that $\mathrm{pH}$ showed negative significant correlation with EC $\left(-0.328^{*}\right)$, EC showed significant positive correlation with phosphorus $\left(0.315^{*}\right)$ and potassium $(0.332 *)$ while organic carbon $\left(0.391^{* *}\right)$, phosphorus $\left(0.403^{* *}\right)$ and potassium $\left(0.403^{* *}\right)$ all were significant and positively correlated with $\mathrm{Fe}$ content in soil, similarly $\mathrm{Fe}\left(0.294^{*}\right)$ and $\mathrm{Ca}\left(0.346^{*}\right)$ both represented significant positive correlation with $\mathrm{Cu}$ while $\mathrm{Cu}$ showed significant negative correlation with $\mathrm{Zn}\left(-0.351^{*}\right)$. $\mathrm{pH}$ represent activity of hydronium ions in soil while EC represents presence of dissolved salt in the soil. Higher the $\mathrm{H}^{+}$ion in soil lower the $\mathrm{pH}$ higher the electrical conductivity (Volk and Jackson, 1963). Information regarding soil pH and EC help farmers know fertility of soil and amount fertilizer to be added to get economic production (Chavai and Kadam, 2016).

It can be concluded from the present investigation that the soils of Chunar are alkaline in nature; soluble salt was extremely low while SOC was medium. Most of plant nutrients were sufficient to meet crop demand while deficiency of nitrogen and boron were matter of great concern since they were extremely low than required by plants. Hence rather than applying all the plant essential nutrients to the soil it's better to give sufficient nutrients in recommended dose while deficient nutrient must be supplied in a dose $25 \%$ more than recommended for maintaining sustainable crop production and soil health in Chunar block of Mirzapur in years to come.

Table.1 Procedures followed for analysis of different soil parameters

\begin{tabular}{|c|c|c|}
\hline Soil test parameter & Method followed & References \\
\hline pH & Combined electrode & Chopra and Kanwar, 1982 \\
\hline EC & Conductivity meter & Sparks, 1996 \\
\hline Organic carbon & Wet digestion & Walkley and Black, 1934 \\
\hline Texture & Hydrometric method & Bouyoucos, 1962 \\
\hline Available N & Alkaline permanganate method & Subbiah and Asija, 1956 \\
\hline Available $\mathbf{P}$ & Olsen method & Olsen et al., 1954 \\
\hline Available K & $1 \mathrm{~N} \mathrm{NH}_{4} \mathrm{OAC}$ method & Hanway and Heidel, 1952 \\
\hline Available S & Turbedimetric method & Chesin and Yien, 1950 \\
\hline Available B & Hot water method & Berger and Troug 1939 \\
\hline $\begin{array}{l}\text { Cationic micronutrients } \\
\quad(\mathrm{Fe}, \mathrm{Mn}, \mathrm{Cu}, \mathrm{Zn})\end{array}$ & $\begin{array}{l}\text { DTPA solution by Atomic } \\
\text { Absorption Spectrophotometer }\end{array}$ & Lindsay and Norvell, 1978 \\
\hline
\end{tabular}


Table.2 Summary statistics for soil available nutrients of some soils of Mirzapur district micronutrients of the soil

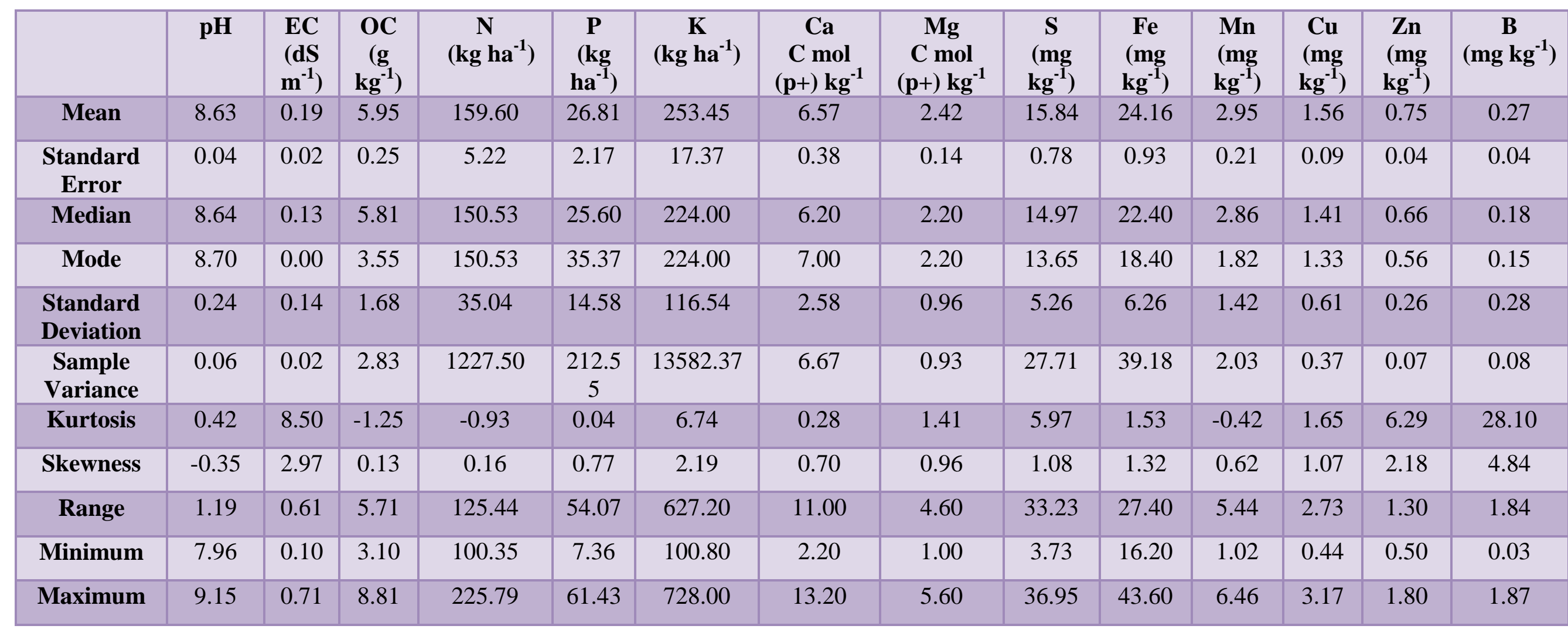


Table.3 Number of Soil Samples falling in different fertility level of major nutrients

\begin{tabular}{|c|c|c|c|}
\hline Soil Test Parameters & \multicolumn{3}{|c|}{ Gangpur (45) } \\
\cline { 2 - 4 } & Low (\%) & Medium (\%) & High (\%) \\
\hline Available N $\left(\mathrm{Kgha}^{-1}\right)$ & $45(100 \%)$ & $0(0.00 \%)$ & $0(0.00 \%)$ \\
\hline Available P $\left(\mathrm{Kgha}^{-1}\right)$ & $6(13.33 \%)$ & $16(35.55 \%)$ & $23(51.11 \%)$ \\
\hline Available K $\left(\mathrm{Kgha}^{-\mathbf{1}}\right)$ & $3(6.66 \%)$ & $22(48.89 \%)$ & $20(44.44 \%)$ \\
\hline
\end{tabular}

Table.4 Number of Soil Samples Falling in Different Fertility level of Secondary Nutrients

\begin{tabular}{|c|c|c|}
\hline Soil test parameters & \multicolumn{2}{|c|}{ Gangpur(45) } \\
\cline { 2 - 3 } & Deficient & Sufficient \\
\hline Exch.Ca(C mol$\left.(\mathbf{p +}) \mathbf{~ k g}^{-1}\right)$ & $0(0.00 \%)$ & $45(100 \%)$ \\
\hline Exch. $\mathbf{M g}\left(\mathbf{C ~ m o l}(\mathbf{p}+) \mathbf{~ k g}^{-1}\right)$ & $0(0.00 \%)$ & $45(100 \%)$ \\
\hline Avail. S(mg kg & $3(6.66 \%)$ & $42(93 . \%)$ \\
\hline
\end{tabular}

Fig.1 Status of available macro and micronutrients in Gangpur village of Mirzapur district

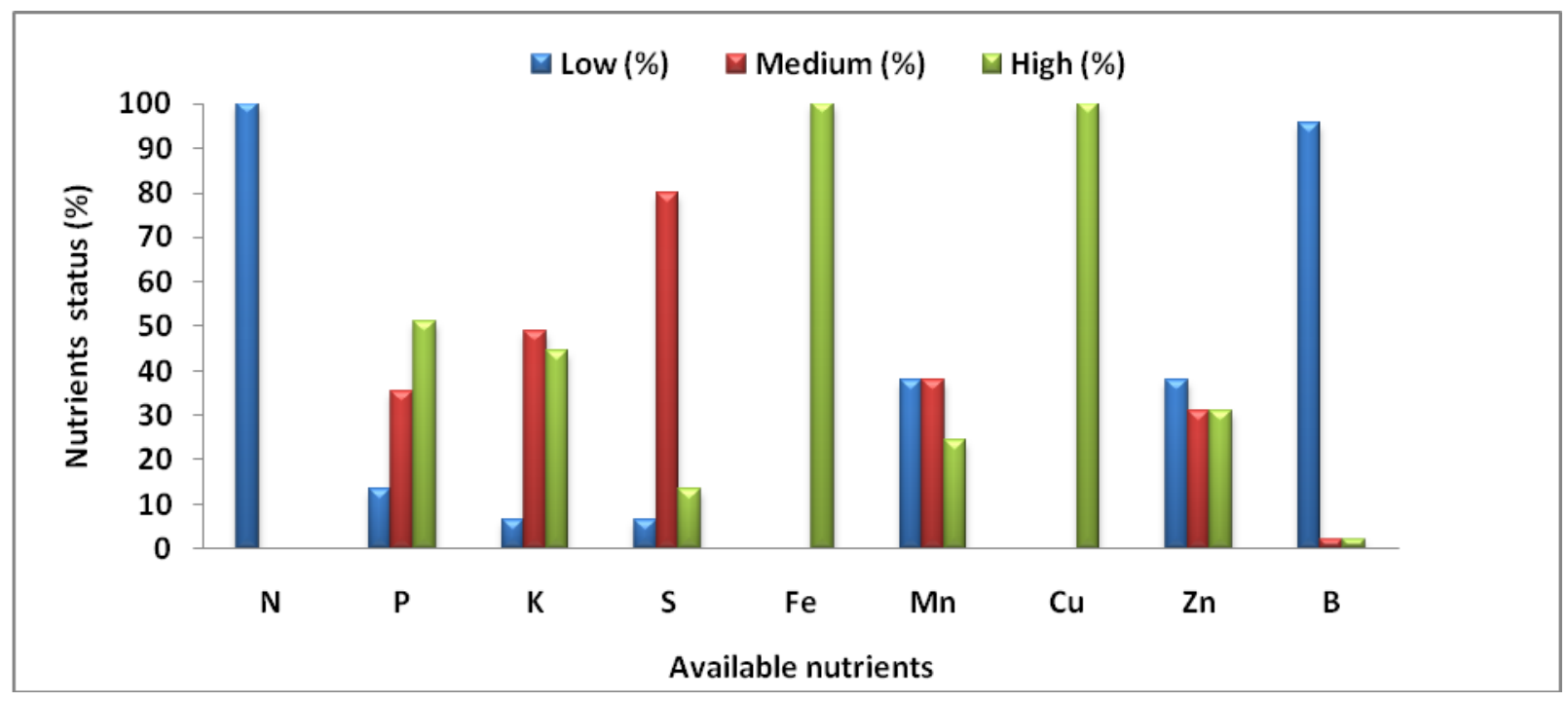


Table.5 Correlation between physicochemical properties and available major, secondary and micronutrients of the soil

\begin{tabular}{|c|c|c|c|c|c|c|c|c|c|c|c|c|c|c|}
\hline & PH & EC & OC & $\mathbf{N}$ & $\mathbf{P}$ & $\mathbf{K}$ & $\mathbf{C a}$ & Mg & $\mathbf{S}$ & $\mathrm{Fe}$ & Mn & $\mathrm{Cu}$ & Zn & B \\
\hline PH & 1.000 & & & & & & & & & & & & & \\
\hline EC & $-0.328 *$ & 1.000 & & & & & & & & & & & & \\
\hline OC & 0.046 & 0.191 & 1.000 & & & & & & & & & & & \\
\hline $\mathbf{N}$ & -0.129 & 0.032 & 0.229 & 1.000 & & & & & & & & & & \\
\hline $\mathbf{P}$ & -0.208 & $0.315^{*}$ & 0.022 & -0.013 & 1.000 & & & & & & & & & \\
\hline $\mathbf{K}$ & -0.128 & $0.332 *$ & 0.135 & -0.153 & $0.444 * *$ & 1.000 & & & & & & & & \\
\hline $\mathbf{C a}$ & -0.135 & -0.282 & 0.034 & -0.208 & -0.088 & -0.027 & 1.000 & & & & & & & \\
\hline Mg & 0.168 & -0.148 & -0.148 & -0.115 & -0.013 & 0.037 & $0.474 * *$ & 1.000 & & & & & & \\
\hline $\mathbf{S}$ & -0.009 & 0.181 & 0.016 & 0.189 & 0.238 & 0.222 & -0.164 & 0.045 & 1.000 & & & & & \\
\hline $\mathbf{F e}$ & -0.148 & 0.051 & $0.391 * *$ & -0.028 & $0.403 * *$ & $0.403 * *$ & 0.069 & 0.260 & 0.027 & 1.000 & & & & \\
\hline Mn & -0.048 & 0.039 & -0.082 & -0.174 & 0.104 & 0.125 & 0.168 & -0.193 & -0.089 & -0.102 & 1.000 & & & \\
\hline $\mathbf{C u}$ & -0.177 & -0.158 & -0.021 & 0.017 & -0.013 & 0.255 & $0.346 *$ & 0.126 & 0.092 & $0.294 *$ & 0.143 & 1.000 & & \\
\hline $\mathbf{Z n}$ & -0.118 & 0.172 & 0.013 & 0.103 & -0.095 & -0.053 & -0.088 & -0.028 & -0.275 & -0.141 & -0.260 & $-0.351 *$ & 1.000 & \\
\hline B & 0.051 & 0.060 & 0.060 & 0.103 & 0.209 & 0.043 & -0.083 & -0.009 & -0.049 & 0.184 & -0.170 & -0.161 & 0.003 & 1.000 \\
\hline
\end{tabular}

*correlation is significant at $5 \%$ level of significance

**correlation is significant at $1 \%$ level of significance 


\section{Acknowledgement}

All the authors are very thankful to the Department of Soil Science and Agricultural Chemistry, Institute of Agricultural Sciences, Banaras Hindu University, Varanasi, UP for providing all the necessary facilities during the work.

\section{References}

Asongwe, G.A., Yerima, B.P., Tenzing, A.S. 2016. Spatial variability of selected physicochemical properties of soils under vegetable cultivation in urban and peri-urban wetland gardens of Bamenda municipality, Cameroon. African Journal of Agricultural Research. 11(2):74-8.

Berger, K.C., Truog, E., 1939. Boron determination in soils and plants. Industrial and Engineering Chemistry Analytical Edition.11(10):540-545.

Berihun, T., Tadele, M., Kebede, F. 2017. The application of biochar on soil acidity and other physicochemical properties of soils in southern Ethiopia. Journal of Plant Nutrition and Soil Science. 180(3):381-388.

Bharteey, P.K., Singh, Y.V., Sukirtee, P.S., Kumar, M, Rai, A.K. 2017. Available Macro Nutrient Status and their Relationship with Soil PhysicoChemical Properties of Mirzapur District of Uttar-Pradesh, India. International Journal of Current Microbiology and Applied Sciences. 6(7): 2829-2837.

Bhattacharyya, R., Tuti, M.D., Bisht, J.K., Bhatt, J.C., Gupta, H.S. 2012. Conservation tillage and fertilization impact on soil aggregation and carbon pools in the Indian Himalayas under an irrigated rice-wheat rotation. Soil Science. 177(3): 218-228.

Bhattacharyya, T., Pal, D.K., Easter, M.,
Batjes, N.H., Milne, E., Gajbhiye, K.S., and Williams, S. 2007. Modelled soil organic carbon stocks and changes in the Indo-Gangetic Plains, India from 1980 to 2030. Agriculture, Ecosystems and environment. 122(1):84-94.

Bouyoucos, G.J. 1962. Hydrometer Method Improved for Making Particle Size Analyses of Soils. Agronomy journal. 54(5): 464-465.

Chavai, A. M., and Kadam, P. M. 2016. Impact of National Horticulture Mission on the pomegranate growers of Maharashtra. International Journal of Tropical Agriculture. 34(4): 10831086.

Cheng, K.L., and Bray, R.H. 1951 Determination of Calcium and Magnesium in soil and plant material. Soil science. 72(6):449-458.

Chesnin, L., and Yien, C.H. 1950. Turbidimetric estimation of Sulphate. Soil Science Society of America. 15(1):149-151.

Chopra, S.L., and Kanwar, J. 1982. Analytical agricultural chemistry.Kalyani Publishers Ludhiana, India.

Das, T.H., Sarkar, D., Bera., and R., Gajbhiye. 2005. Water retention characteristics of some typical Inceptisols developed on the alluvial plain of Damodar catchment (part), West Bengal.Journal of Soil and Water Conservation. 33(2):123-127.

Daulta, R., Rani, J., and Yadav, A. 2014. Effect of sugar mill effluent on physicochemical properties of soil at Panipat City, India. International Archive of Applied Sciences and Technology. 5(2):6-12

Devarajan, R., Hanumappa, K.R., and Kuppan, N. 2015. The study of change in physicochemical properties of soil due to cement dust pollution- a hazardous terrorization to the ecosystem. Canadian Journal of Pure 
and Applied Sciences. 9(1):3193-3200

Dhaliwal, A. K., Gupta, R. K., YadvinderSingh, and Bijay-Singh. 2006. Potassium fixation and release characteristics of some benchmark soil series under rice-wheat cropping system in the Indo- Gangetic plains of northwestern India. Communications in soil science and plant analysis. 37(05-06), 827-845.

Doneriya, B.S., Meena, R., Meena, V.S., Meena, R.S. and Dadhich R. 2013. Soil fertility status of vegetable and pulses growing area under Marihan block in Vindhyan region of Mirzapur district. An Asian Journal of Soil Science. 8(2):286-289.

Ekka, A.A., Kumar, D., Singh, A.P., Singh, A. 2017. Variation in physicochemical properties of soil under a different agri-horti system in Vindhyan region. Journal of Applied and Natural Science. 9(2): 1187-1193.

Emmauel, S., and Oguche, A.O. 2013. Studies of Physicochemical Properties of Rhizosphere of Elaeis guinensis in Ayingba. International Journal of Scientific Research and Knowledge. 1(9):358-362.

Eswaran, H., Berg, E.V.B., and Reich, P. 1992. Organic Carbon in Soils of the World Soil. Science Society of America Journal Abstract. 5(1):192194.

Ghosh, P. 2017. Characterization of soils of the Mirzapur district of Uttar Pradesh (Doctoral dissertation, Department of Soil Science and Agricultural Chemistry, Institute of agricultural Science, BHU. Varanasi).

Hanway, J.J., and Heidel, H. 1952. Soil analysis methods as used in Iowa state college soil testing laboratory Iowa agric. 57(1): 187-193.

Jha, P., Biswas, A.K., Lakaria, B.L., Saha, R., Singh, M., and Rao, A.S. 2014.
Predicting total organic carbon content of soils from Walkley and Black analysis. Communications in soil science and plant analysis. 45(6):713725.

Kashiwar, S.R., Nath, T., Kumar, D., Kundu, M.C., Dongarwa, U.R., Rajput, B.S., and Dongarwar, L.N. 2018. Evaluation of Soil Fertility Status of Rajiv Gandhi South Campus (Banaras Hindu University), Mirzapur, Uttar Pradesh by Using GIS. International Journal of Current Microbiology and Applied Sciences. 7:3825-383.

Krishan. G., Chandniha, S.K., Lohani, A.K., Yadav, B.K., Arora, N.K., Singh, S., Kumar, C.P., Sharma, L.M., and Bhardwaj, A.K. 2018. Assessment of Heavy Metals in Relation to Soil Pollution at Mewat, Haryana, India. Current World Environment. 13(3): 299-306.

Kumar, R., Rawat, K.S., Singh, J., Singh, A., and Rai, A., 2013. Soil aggregation dynamics and carbon sequestration. Journal of Applied and Natural Science. 5(1): 250-267

Ladha, J. K., Pathak, H., Tirol-Padre, A., Dawe, D., and Gupta, R. K. 2003. Productivity trends in intensive ricewheat cropping systems in Asia. Improving the Productivity and Sustainability of Rice-Wheat Systems: Issues and Impacts, (improvingthepro), 45-76.

Lindsay, W.L., and Norvell, W.A., 1978. Development of a DTPA soil test for zinc, iron, manganese, and copper. Soil Science Society of America Journal. 42(3): 421-428.

Madhu, M., Serhachalam, N., Nalatwadmath, K., and Nimje, P.M. 1997. Effect of organic and inorganic fertilizers on yield of crops and physicochemical properties of soil in high hills of NilgiriIndian. Journal of Soil 
Conservation. 25(3): 241-245.

Medina, E., Paredes, C., Bustamante, M.A., Moral, R., and Moreno-Caselles, J. 2012. Relationships between soil physicochemical, chemical and biological properties in a soil amended with the spent mushroom substrate. Geoderma.173-174: 152-161.

Meena, R.S., and Mathur, A.K. 2017. Available Micronutrients in Relation to Soil Properties of Ghatol Tehsil, Banswara District of Rajasthan, India. International Journal of Current Microbiology and Applied Sciences. 6(7): 102-108.

Olsen, S.R. 1954. Estimation of available phosphorus in soils by extraction with sodium bicarbonate. United States Department of Agriculture; Washington.

Pareta, D.K., Ojha, R.K., and David, A.A. 2009. Response of $\mathrm{N}$ and $\mathrm{Zn}$ on physicochemical properties of soil and yield of wheat under alluvial soil condition. Environment and Ecology. 27(4B): 1895-1898.

Parker, D.R., and Gardner, E.H. 1981. The determination of hot- water- soluble boron in some acid Oregon soils using a modified azomethine-H procedure. Communications in Soil Science and Plant Analysis. 12(12):1311-1322.

Rai, A., and Singh, S. 2018(a). Forms of sulphur in some black soils of Varanasi district of Uttar Pradesh. Journal of Experimental Biology and Agricultural Sciences. 6(6): 983-989.

Rai, A., and Singh, S. 2018 (b). Available nutrients status in black soils of Varanasi district of the eastern part of Uttar Pradesh. Journal of Applied and Natural Science.10(4): 1238 -1242.

Sahrawat, K.L., Wani, S.P., Pardhasaradhi, G. and Murthy, K.V.S. 2010. Diagnosis of secondary and micronutrient deficiencies and their management in rainfed agro-ecosystems: Case study from Indian semi-arid tropics. Communications in Soil Science and Plant Analysis. 41: 346-360.

Sen, P., and Majumdar, K. 2006. The fifth international conference of the Asian Federation for Information Technology in Agriculture, J N Tata Auditorium, Indian Institute of Science Campus, Bangalore, India, pp 653-660.

Sharma, R.P., Yadav, R.B., Lama, T.D., Bahadur, A., and Singh, K.P. 2013. Status of secondary nutrients vis-a-vis soil site-characteristics of vegetable growing soils of Varanasi. Vegetable Science. 40(1): 65-68.

Singh, S. K., Dey, P., Singh, S., Sharma, P. K., Singh, Y. V., Latare, A. M. and Verma, S. S. 2015. Emergence of Boron and Sulphur deficiency in soils of Chandauli, Mirzapur, Sant Ravidas Nagar and Varanasi districts of Eastern Uttar Pradesh. Journal of the Indian Society of Soil Science. 63(2): 200208.

Singh, S. N., Latare, A. M., and Singh, S. K. 2017. Soil Fertility Status of Majhwa Block of Mirzapur District of Eastern UP, India. Journal of Current Microbiology and Applied Sciences. 6(9):2019-2026.

Singh, S., and Gangwar, B. M. 1971. Mineralogical Study of the Fine Sands and Rock Fragments of the Vindhyan Soils of Mirzapur. Journal of the Indian Society of Soil Science. 19(1):59-63.

Srinivasarao, C.H., Wani, S.P., Sahrawat, K.L., Krishnappa, K. and Rajasekhara, and Rao, B.K. 2010. Effect of balanced nutrition on yield and economics of vegetable crops in participatory watersheds in Karnataka. Indian Journal of Fertilizers. 6: 39-42.

Stewart, W. M., Dibb, D. W., Johnston, A. E., and Smyth, T. J. 2005. The 
contribution of commercial fertilizer nutrients to food production. Agronomy Journal. 97(1): 1-6.

Subbiah, B.V., Asija, GL. 1956. Alkaline method for determination of mineralizable nitrogen. Current science. 25(2): 259-260.

Timsina, J., and Connor, D. J. 2001. Productivity and management of ricewheat cropping systems: issues and challenges. Field crops research. 69(2): 93-132.

Tiwari, R.C., Agarwal, H.P., Maurya, B.R. and Narayan, D. 2003. Organic matter recycling and enrichment. Department of Soil Science and Agricultural Chemistry, Institute of Agricultural Sciences, Banaras Hindu University, Varanasi. Final report of the research project, submitted to ICAR (NATP), New Delhi. pp. 36-41.

Volk, V. V., and Jackson, M. L. (1963). Inorganic $\mathrm{pH}$ dependent cation exchange charge of soils. Clays and clay minerals. 12(1): 281-295.

Yadav, R. L., Dwivedi, B. S., Singh, V. K. and Shukla, A. K. 2001. Nutrient mining and apparent balances in different agro climatic Zones of Uttar Pradesh. Fertiliser News. 46(4): 13-31.

\section{How to cite this article:}

Puja Singh, Surendra Singh and Ashish Rai. 2019. Delineation of Soil Fertility and Correlation Study of Different Nutrients in Soils of Chunar, Mirzapur. Int.J.Curr.Microbiol.App.Sci. 8(11): 36-46. doi: https://doi.org/10.20546/ijcmas.2019.811.005 